(c) American Dairy Science Association, 2006.

\title{
Longer Milking Intervals Alter Mammary Epithelial Permeability and the Udder's Ability to Extract Nutrients
}

\author{
E. Delamaire and J. Guinard-Flament ${ }^{1}$ \\ Unité Mixte de Recherches INRA/Agrocampus Rennes Production du Lait, 33590 Saint-Gilles, France
}

\begin{abstract}
Increasing the milking interval decreases milk yield and modifies milk composition. To gain a clearer understanding of the regulation of milk yield and composition, a study was conducted to establish the response curves of nutrient extraction by the mammary gland and mammary epithelial permeability in response to increasing milking intervals. Four multiparous lactating dairy cows were milked at 8-, 12-, 16-, or 24-h intervals over a period of $7 \mathrm{~d}$ using a Latin square design. Between the 8- and 24-h milking intervals, milk yield and milk protein levels fell curvilinearly from 38.2 to $29.2 \mathrm{~kg} / \mathrm{d}$ and from 1,086 to $827 \mathrm{~g} / \mathrm{d}$, respectively. Milk fat yield decreased linearly from 1,475 to $1,235 \mathrm{~g} / \mathrm{d}$. Indicators of the opening of tight junctions increased linearly with increasing milking intervals: milk BSA increased from 148 to $207 \mathrm{mg} / \mathrm{L}$ and plasma lactose increased from 22.9 to $32.0 \mathrm{mg} / \mathrm{L}$. The mammary gland's ability to extract nutrients decreased with increasing milking intervals. Extraction rates of glucose, $\beta$ hydroxybutyrate, and total glycerol decreased significantly (from 27.2 to $23.3 \%$, from 42.3 to $34.4 \%$, from 36.6 to $30.8 \%$ between 8 - and 24 -h milking intervals, respectively), and not significantly for $\alpha$-amino nitrogen (from 23.2 to $20.0 \%$ ). The extraction rate of acetate remained constant. Moreover, the extraction of milk fat precursors appeared to be less regulated than those of the precursors of milk protein and lactose, which could partly explain why milk yield and milk protein yield decreased more than milk fat yield. The arteriovenous differences of $\beta$-hydroxybutyrate and total glycerol remained constant, whereas those of glucose decreased significantly from 0.98 to $0.87 \pm 0.05 \mathrm{mmol} / \mathrm{L}$ and not significantly from 0.74 to $0.64 \pm 0.12 \mathrm{mmol} / \mathrm{L}$ for $\alpha$ amino nitrogen. As a result, the mammary gland's ability to extract nutrients appears to be downregulated explaining partly the decrease in daily milk yield observed in response to increased milking intervals.
\end{abstract}

Received July 18, 2005.

Accepted December 13, 2005.

${ }^{1}$ Corresponding author: Jocelyne.Flament@agrocampus-rennes.fr
Key words: dairy cow, milking frequency, mammary nutrient extraction, mammary epithelium permeability

\section{INTRODUCTION}

Changes in the milking frequency modify milk yield and composition to a more or less marked extent depending on the component (lactose, fat, or protein). Switching cows from thrice-daily to twice-daily milking results in a decrease in milk yield of 10 to $15 \%$ on average (Pearson et al., 1979; DePeters et al., 1985; Szûcs et al., 1988; Barnes et al., 1990). Although DePeters et al. (1985) did not see any variation in the milk fat and protein contents, other authors have reported an average increase in the milk fat content of $2 \mathrm{~g} / \mathrm{kg}$ (Pearson et al., 1979; Szûcs et al., 1988; Barnes et al., 1990) when milking was reduced to twice daily. Throughout the lactation period, milk protein content was slightly affected; Sorensen et al. (2001) observed a $-0.3 \mathrm{~g} / \mathrm{L}$ fall in protein levels, whereas Klei et al. (1997) reported an increase of $0.9 \mathrm{~g} / \mathrm{kg}$. When the milking frequency is reduced from twice to once a day, loss of milk yield and changes in milk composition are more accentuated than when reducing from 3 to 2 milkings per day. Milk yield falls by 35 to $50 \%$ throughout lactation and by an average of $20 \%$ over periods of 1 to 12 wk (Davis et al., 1999). During most of those studies, the milk fat content rose because of a concentration effect by an average of $2.8 \mathrm{~g} / \mathrm{kg}$, although this increase could be as much as $6.4 \mathrm{~g} / \mathrm{kg}$ (Rémond and Pomiès, 2004). Protein content tends to rise by an average of $1.5 \mathrm{~g} / \mathrm{kg}$ (Davis et al., 1999; Rémond and Pomiès, 2004).

Milk yield and composition are partly linked to the quantity of nutrients used by the mammary gland. Although this quantity is a function of the nutrient flux into the gland, it also depends on the gland's ability to extract and use the nutrients to synthesize and secrete milk constituents. Modifications of the nutrient extraction ability of the mammary gland could be one of the mechanisms implicated in the reduction in milk component production in response to increasing milking intervals. In fact, variations in the mammary nutrient extraction could depend on the milking interval to which animals are subjected and on the type of nutrient considered. These differences could explain why the fall in 
milk production is more marked during a change from twice-daily to once-daily milking than from thrice-daily to twice-daily milking and why milk fat content varies differently from the milk protein content. Indeed, after a 2-d interruption of milking in the goat, Fleet and Peaker (1978) observed a reduction in the arteriovenous difference (AVD) of glucose and acetate. In the dairy cow milked twice daily, Thivierge et al. (2002) observed that the AVD of amino acids and lipogenesis, estimated from the respiratory quotient, peaks during the first 8 $\mathrm{h}$ after milking and then declines.

Tight junctions are complexes located at the apex of the lateral membranes of epithelial cells. Tight junctions ensure the cohesion of epithelial cells and thus guarantee a relative impermeability of the mammary epithelium. Barrier and fence functions have been attributed to tight junctions. In barrier function, tight junctions regulate the paracellular movement of ions and small solutes across the epithelial or endothelial cell bed. In fence function, tight junctions separate the plasma membrane into basolateral and apical domains and participate in maintaining the asymmetric distribution of ion channels, pumps, and carriers in the plasma membrane (Schneeberger and Lynch, 1992). As the milking frequency decreases, tight junctions open causing an increase in the mammary epithelium permeability, which allows the passage of ions $\left(\mathrm{Na}^{+}, \mathrm{K}^{+}\right)$and solutes (lactose, BSA) according to the law of mass action (Schneeberger and Lynch, 1992). According to Davis et al. (1999) and Stelwagen (2001), these tight junctions may be involved in regulating milk production in dairy ruminants. In the goat milked once daily or after a 36-h interval, the increase in the mammary epithelial permeability coincides with a reduction in milk secretion (Stelwagen et al., 1994). In addition, the artificial opening of the tight junctions by a calcium chelating agent (EGTA, ethylene glycol bis(2-aminoethyl ether)-N,N, $\mathrm{N}^{\prime}, \mathrm{N}^{\prime}$-tetraacetic acid) in the goat causes a $15 \%$ decrease in milk yield, which is comparable to the one observed when animals are subjected to once-daily milking (Stelwagen et al., 1995). In dairy cows milked once a day, the opening of the tight junctions has clearly been demonstrated (Davis et al., 1999; Stelwagen, 2001). Tight junctions could also be affected in cows milked 3 times in $2 \mathrm{~d}$ (Rémond and Boît, 1997). However, no clear evidence was provided about the role of tight junctions in the regulation of milk yield in this species.

An experiment was conducted to get a better understanding of the role of the mammary gland's ability to extract nutrients and of the mammary epithelial permeability when daily milk production is reduced by increased milking intervals from 8 to $24 \mathrm{~h}$ in dairy cattle. The response curves of mammary gland extrac- tions of nutrient precursors for milk components in relation to the opening of tight junctions were established in dairy cows receiving 4 types of milking frequency.

\section{MATERIALS AND METHODS}

\section{Treatments, Cows, and Experimental Design}

Treatments consisted of 4 milking frequencies under a constant level of feeding: thrice-daily milking, twicedaily milking, milking 3 times in $2 \mathrm{~d}$, and once-daily milking, corresponding to 8-, 12-, 16-, and 24-h milking intervals, respectively.

Four multiparous Holstein cows (635 $\pm 30 \mathrm{~kg}$ of BW) in their second or third lactation at $72 \pm 3 \mathrm{~d}$ postpartum at the beginning of the experiment were used. The cows were surgically prepared to estimate the mammary extraction of nutrients on the left half udder of each cow, according to the methods described by Guinard et al. (1994). Arterial blood was drawn from the carotid, which is more accessible than the external pudic artery. The venous blood of each half-udder returns toward the heart through 3 veins: the external pudic vein, the subcutaneous abdominal vein, and the perineal vein. This last vein carries less than $10 \%$ of the blood leaving the udder and may be neglected according to Linzell (1974). The return of the venous blood toward the heart also depends on the animal's physical position. In cows during second lactation or beyond, as in this study, the venous blood returns toward the heart principally via the subcutaneous abdominal vein when the animal is in an upright position. In a supine position, the venous blood returns toward the heart via the external pudic vein (Linzell, 1974). For these reasons, the venous blood was drawn from the subcutaneous abdominal vein, which was more accessible when cows were standing. Surgical preparation procedures were reviewed and approved by the Animal Care Committee of the French Ministry of Agriculture. One month before the beginning of the experiment, 2 permanent catheters (polyurethane catheter tubing, i.d. $1.0 \mathrm{~mm}$, o.d. $1.7 \mathrm{~mm}$; UNO, Roestvaststaal B.V., Netherlands) were inserted into the left carotid and subcutaneous abdominal vein, against the bloodstream, to measure the AVD in nutrient concentrations. The arterial and venous catheters were protected by silastic tubing (Silclear grade medical silicone tubing, i.d. $1.57 \mathrm{~mm}$, o.d. $3.18 \mathrm{~mm}$; VWR International SAS, Briare, France). A Dacron ring (Mersutures, TS53, Ethicon, Issy Les Moulineaux, France) was fixed around the catheters as they exited the body to prevent infection.

The experiment was conducted using a Latin square design with 4 cows and 5 periods. A fifth period was subsequently added because of a damaged venous catheter in 1 cow during the first period. Another cow was 
absent during the third period because of digestive problems. During the fifth period, those 2 cows received the treatment planned for their respective first and third periods, whereas the other 2 cows were subjected to the 2 extreme treatments; i.e., once- and thrice-daily milking. Each period covered $2 \mathrm{wk}$. The first week provided a transition when cows were milked twice daily $(0630$ and $1830 \mathrm{~h})$. The second week of each period was the experimental week and cows were milked according to treatments allocated (thrice-daily milking: 0630, 1430, and $2230 \mathrm{~h}$; twice-daily milking: 0630 and 1830 h; 3 milkings in $2 \mathrm{~d}$ : 0630, 2230, and $1430 \mathrm{~h}$ the next day; and once-daily milking: $0630 \mathrm{~h}$ ). During each experimental week, each half-udder was milked separately to tie in with the AVD measurements. No mastitis was observed during this experiment $(\mathrm{SCC}=91 \pm$ $48 \times 10^{3} / \mathrm{mL}$ ).

\section{Feeding}

The quantities of feed offered to animals were limited to avoid feed refusal and to ensure a constant feed supply throughout the experimental period. Cows received a diet that would cover $105 \%$ of the energy and protein requirements calculated for cows milked twice daily, to compensate for the increase in milk yield observed with thrice-daily milking (INRA, 1989). The diet consisted of $59.5 \%$ corn silage, $20.2 \%$ concentrates (containing $22 \%$ barley, $21.5 \%$ wheat, $20 \%$ beet pulp, $17 \%$ fine wheat bran, $15 \%$ soybean meal, $2 \%$ molasses, and $2.5 \%$ minerals on a DM basis), $10.0 \%$ formaldehyde-treated soybean meal, and $10.3 \%$ alfalfa. This was supplemented by $226 \mathrm{~g}$ of minerals and vitamins per day. The cows were fed twice daily and had access to food for 8 $\mathrm{h}$ after each allocation (from 0630 to $1430 \mathrm{~h}$ and from 1830 to $0230 \mathrm{~h})$. The DM content of corn silage was determined daily to adjust the quantities offered. Refusals were weighed daily.

\section{Measurements, Sampling, and Analyses}

Milk. Milk yield was recorded at each milking. Fat and protein contents were determined by infrared analysis (Milkoscan, Foss Electric, Hillerød, Denmark). On the last day of each period, $2 \mathrm{~L}$ of milk was collected during each milking from the left half-udder and stored at $-20^{\circ} \mathrm{C}$ for subsequent milk composition analysis. Before analysis, milk samples were pooled per cow and per period, each pool being balanced from the milk yield of each milking to obtain a daily representative milk sample. The milk was analyzed for lactose using a colorimetric enzymatic reaction (kit for lactose/D-galactose, Roche, Meylan, France) and a multiparameter analyzer (Kone Instruments Corporation, Espoo, Finland). The milk was analyzed for total $\mathrm{N}$ using Kjeldahl procedure and casein (precipitation at pH 4.6 with $10 \%$ acetic acid and $1 M$ sodium acetate). Milk fatty acids were analyzed to determine the percentages of short, medium, and long fatty acids, according to the method described by Hurtaud et al. (1993), based on the method developed by Bauchard and Duboisset (1983). Briefly, milk fatty acids were transesterified with $1 \mathrm{~mL}$ of a methanol$\mathrm{NaOH}$ solution (100/2, vol/wt) followed by $0.5 \mathrm{~mL}$ of methanol/boron trifluoride (100/20, vol/vol), and $2 \mathrm{~mL}$ of hexane. Fatty acid methyl esters were then injected into a gas chromatograph (Varian 3400, Les Ulis, France) equipped with an electron ionization detector. The carrier gas was helium. The oven temperature was programmed from 70 to $220^{\circ} \mathrm{C}$ at $100^{\circ} \mathrm{C} / \mathrm{min}$, and held for $32 \mathrm{~min}$. The injector and detector temperatures were 220 and $250^{\circ} \mathrm{C}$, respectively. To analyze the milk metabolites involved in lactose synthesis (glucose, glucose-6phosphate, and glucose-1-phosphate), milk was deproteinized with $5 \mathrm{M} \mathrm{HClO}_{4}$ before storage at $-20^{\circ} \mathrm{C}$, and later analyzed according to the methods described by Faulkner (1980). For estimates of mammary epithelial permeability, milk $\mathrm{Na}^{+}$and $\mathrm{K}^{+}$concentrations were measured by flame spectrometry (SpectraAA-20, Varian). The milk BSA concentration was measured using a radial immunodiffusion assay (rabbit anti-BSA antiserum; IDBiotech, Theix, France) (Levieux, 1991).

Blood. Cows were standing during blood sampling. Blood samples were collected on the last day of each period at $0.5,1.5,3.0,5.5,8.5,11.5,12.5,13.5,15.0$, $17.5,20.5$, and $23.5 \mathrm{~h}$ after the first morning milking to consider the variations in the plasma levels of the nutrient precursors of milk constituents simultaneously from the artery and vein using heparinized syringes (S-Monovette, $7.5 \mathrm{~mL}$; Sarstedt, Nümbrecht, Germany). Blood samples were kept on ice and centrifuged at $2,500 \times g$ for $10 \mathrm{~min}$ at $4^{\circ} \mathrm{C}$. Plasma metabolites were pooled per cow and per period and assayed using colorimetric enzymatic reactions with a multiparameter analyzer (Kone Instruments Corporation). To analyze the extraction of milk precursors by the mammary gland from blood plasma, the concentration of glucose (precursor of lactose), $\alpha$-amino nitrogen (precursor of milk proteins), and acetate, BHBA, NEFA, and total glycerol (precursors of milk fat) were determined from the arterial and venous plasma. Heparinized plasma was used to determine the concentrations of glucose (hexokinase, glucose-6-phosphate dehydrogenase; glucose hexokinase kit, Roche), NEFA (acetyl-CoA synthetase, acyl-CoA oxydase, peroxidase method; Wako kit, Oxoid S.A., Dardilly, France), total glycerol (lipase, glycerol kinase, glycerol-3-phosphate oxidase, peroxidase method; Biotrol Diagnostic, Chennevière Les Louvres, France) and BHBA (3-HB-dehydrogenase method; 
3-dimensional hydroxybutyrate kit, Randox Laboratories Ltd., Crumlin, UK). Deproteinized plasma (with $50 \%, \mathrm{vol} / \mathrm{vol}$ perchloric acid by filtration) was used to measure concentrations of acetate (acetyl-CoA synthetase, citrate synthetase, malate dehydrogenase method; Sigma, Saint-Quentin Fallavier, France) and $\alpha$-amino nitrogen (disodium tetraborate decahydrate, 2,4,6 trinitrobenzene sulfonic acid hydrate; Merck, Fontenay Sous Bois, France). For estimations of mammary epithelial permeability, venous plasma lactose concentrations were determined from blood sampled on the last day of each period at the same time for plasma metabolite determinations, with 1 additional sample being collected $16.5 \mathrm{~h}$ after the first morning milking. Plasma lactose levels were determined using colorimetric enzymatic reactions (kit for lactose/D-galactose, Roche) with a multiparameter analyzer.

\section{Calculations and Statistical Analyses}

Milk performances and intakes were determined using averaged data for the last $7 \mathrm{~d}$ of the period. The ability of the mammary gland to extract nutrients from the blood was estimated using the AVD (plasma arterial concentration - plasma venous concentration) and the extraction rate; that is, AVD divided by the arterial plasma concentration $\times 100$.

The data were analyzed using the GLM procedure under SAS (SAS Institute, 1990) according to the following statistical model:

$$
\mathrm{Y}_{\mathrm{ijk}}=\mu+\operatorname{cow}_{\mathrm{i}}+\operatorname{period}_{\mathrm{j}}+\text { treatment }_{\mathrm{k}}+\varepsilon_{\mathrm{ijk}}
$$

where $Y_{i j k}$ is the variable dependent on cow $i$ receiving treatment $\mathrm{k}$ for the period $\mathrm{j}, \mu$ is the average, and $\varepsilon_{\mathrm{ijk}}$ is the residual error associated with each ijk observation. The linear, quadratic, and cubic effects of treatments were analyzed by orthogonal contrasts. Results were expressed as least squares means with root mean square errors. The significance threshold was set at $P$ $\leq 0.05$ and trends were noted at $P \leq 0.10$.

\section{RESULTS}

\section{Feeding, Milk Yield, and Milk Composition}

The intakes of DM, energy, and proteins that will be truly digested in the small intestine (PDI) were not modified by the different treatments (Table 1). Milk yield and the FCM yield decreased curvilinearly $(P \leq$ 0.05 ; Table 1). Milk and FCM yields did not change between 8 - and 12-h milking intervals but decreased by 3.3 and $2.6 \mathrm{~kg} / \mathrm{d}$, respectively, between $12-$ and 16 $\mathrm{h}$ milking intervals. Those reductions were amplified with the 24-h milking interval (decreases of 5.8 and 3.8 $\mathrm{kg} / \mathrm{d}$ between 16 - and 24-h milking intervals, respectively). Milk protein yields decreased curvilinearly ( $P$ $\leq 0.01$ ), decreasing by $78 \mathrm{~g} / \mathrm{d}$ between the 12 - and 16$\mathrm{h}$ milking intervals and by $164 \mathrm{~g} / \mathrm{d}$ between 16 - and $24-$ $\mathrm{h}$ milking intervals. The milk protein content tended to vary quadratically, falling to a minimum with the 12 $\mathrm{h}$ milking interval treatment. Milk fat yield decreased linearly by $240 \mathrm{~g} / \mathrm{d}$ and the milk fat content increased curvilinearly to peak at the 24 -h milking interval. The energy balance increased curvilinearly with lengthening milking intervals. It was negative with 8 - and 12 $\mathrm{h}$ milking intervals and became positive with the $16-\mathrm{h}$ milking interval. The PDI balance increased curvilinearly by $442 \mathrm{~g} / \mathrm{d}$ between the 12- and 24-h milking intervals.

Similar variations were observed in the left half-udder milk collected on the last day of the period, with the exception of milk fat yield, which tended to change cubically because of higher values observed at the 16$\mathrm{h}$ milking interval and lower values for 24-h intervals (Table 2$)$. Milk casein yield decreased linearly $(P \leq 0.01)$ and tended to decrease quadratically $(P \leq 0.10)$ with increasing milking interval. Milk casein content tended $(P \leq 0.10)$ to decrease linearly by $0.7 \mathrm{~g} / \mathrm{kg}$ with the change primarily between the 16- and 24-h milking intervals. Whey protein yield did not vary with treatment but whey protein content increased linearly ( $P$ $\leq 0.05$ ) by $0.8 \mathrm{~g} / \mathrm{kg}$ between the 8 - and 24 -h milking intervals. The casein/whey protein ratio tended to decrease curvilinearly. Between the 8- and 12-h milking intervals, the ratio remained constant $(\sim 4.55)$ but decreased from the 12 -h milking interval by 0.72 points to 3.84 at the 24 -h milking interval. The milk lactose yield decreased linearly by $170 \mathrm{~g} / \mathrm{d}$ with increasing milking intervals. Changes in lactose content were small with a decrease of just $1.9 \mathrm{~g} / \mathrm{kg}$ between 16 - and 24-h milking intervals (linear and quadratic effects; $P$ $\leq 0.10$ ).

Changes to the milk fatty acid composition were minor (Table 2). Levels of short-chain fatty acids $\left(\mathrm{C}_{4}\right.$ to $\mathrm{C}_{10}$ ) decreased linearly from 13.4 to $12.8 \%$ (from 83 to $72 \mathrm{~g} / \mathrm{d})$, whereas medium-chain fatty acids $\left(\mathrm{C}_{11}\right.$ to $\left.\mathrm{C}_{14}\right)$ were not modified by treatments $(103 \mathrm{~g} / \mathrm{d})$. Levels of $\mathrm{C}_{16}$ fatty acids were higher as milking intervals increased but variations were cubic, reaching a maximum with 12- and 24-h milking intervals (in g/d: 225, 230, 242, and 216 at 8-, 12-, 16-, and 24-h milking interval, respectively). Percentages of $\mathrm{C}_{18}$ fatty acids tended to vary cubically, reaching a maximum with the 8 - and 16-h milking intervals (207 and $220 \mathrm{~g} / \mathrm{d}$ ).

The glucose content in milk changed curvilinearly (Table 3 ) in that glucose was similar at the 8- and 12$\mathrm{h}$ milking intervals but was lower for milking intervals 
Table 1. Effect of milking frequency on feed intake and milk yield averaged over the $7 \mathrm{~d}$ of the experimental week of treatments in dairy cows

\begin{tabular}{|c|c|c|c|c|c|c|c|c|c|}
\hline & & \multicolumn{4}{|c|}{ Milking interval (h) } & \multirow[b]{2}{*}{$\mathrm{RMSE}^{1}$} & \multicolumn{3}{|c|}{ Effect $^{2}$} \\
\hline & & 8 & 12 & 16 & 24 & & $\mathrm{~L}$ & Q & $\mathrm{C}$ \\
\hline DMI, kg/d & & 23.2 & 24.0 & 23.6 & 23.9 & 0.86 & NS & NS & NS \\
\hline \multirow{2}{*}{ Energy, Mcal/d } & Intake & 35.0 & 35.4 & 35.2 & 35.0 & 1.18 & NS & NS & NS \\
\hline & Balance & -2.27 & -0.98 & 0.57 & 5.18 & 1.66 & $* * *$ & $*$ & NS \\
\hline \multirow[t]{2}{*}{$\mathrm{PDI},{ }^{3} \mathrm{~g} / \mathrm{d}$} & Intake & 2,255 & 2,287 & 2,273 & 2,268 & 61.4 & NS & NS & NS \\
\hline & Balance & 116 & 203 & 272 & 645 & 73.4 & *** & $*$ & $\dagger$ \\
\hline Milk yield, kg/d & & 38.2 & 38.3 & 35.0 & 29.2 & 1.78 & $* * *$ & $* *$ & NS \\
\hline FCM yield, kg/d & & 37.4 & 36.6 & 34.0 & 30.2 & 1.77 & $* * *$ & * & NS \\
\hline \multicolumn{10}{|l|}{ Milk protein } \\
\hline $\mathrm{g} / \mathrm{d}$ & & 1,086 & 1,069 & 991 & 827 & 52.6 & $* * *$ & $* *$ & NS \\
\hline $\mathrm{g} / \mathrm{kg}$ & & 28.6 & 27.8 & 28.4 & 28.7 & 0.61 & NS & $\dagger$ & NS \\
\hline \multicolumn{10}{|l|}{ Milk fat } \\
\hline $\mathrm{g} / \mathrm{d}$ & & 1,475 & 1,423 & 1,334 & 1,235 & 79.7 & ** & NS & $\mathrm{NS}$ \\
\hline $\mathrm{g} / \mathrm{kg}$ & & 38.8 & 37.1 & 38.3 & 43.3 & 1.78 & * & $* *$ & NS \\
\hline
\end{tabular}

${ }^{1} \mathrm{RMSE}=$ Root mean square error.

${ }^{2}$ Linear (L), quadratic (Q), and cubic (C) effects.

${ }^{3} \mathrm{PDI}=$ Protein truly digested in the small intestine (INRA, 1989).

$\dagger P \leq 0.10 ; * P \leq 0.05 ; * * P \leq 0.01 ; * * * P \leq 0.001$.

$>12$ h. Glucose-6-phosphate and the ratio of glucose-6phosphate:glucose in milk remained unchanged when milking intervals became longer. Glucose-1-phosphate level and the ratio of glucose-1-phosphate:glucose in milk decreased linearly by $47.1 \mu \mathrm{mol} / \mathrm{L}$ and 0.44 points with increasing milking intervals, respectively.

\section{Nutrient Extraction by the Mammary Gland}

Arterial glucose concentrations increased quadratically with increasing milking intervals (Table 4). They were not modified between the 8- and 16-h milking intervals, but increased by $0.21 \mathrm{mmol} / \mathrm{L}$ between the

Table 2. Effect of milking frequency on milk yield and milk composition after $7 \mathrm{~d}$ of treatments from the left half udder in dairy cows

\begin{tabular}{|c|c|c|c|c|c|c|c|c|}
\hline & \multicolumn{4}{|c|}{ Milking interval (h) } & \multirow[b]{2}{*}{$\mathrm{RMSE}^{1}$} & \multicolumn{3}{|c|}{ Effect $^{2}$} \\
\hline & 8 & 12 & 16 & 24 & & $\mathrm{~L}$ & Q & $\mathrm{C}$ \\
\hline Milk yield, kg/d & 20.2 & 19.1 & 18.6 & 15.6 & 1.65 & $* *$ & NS & NS \\
\hline \multicolumn{9}{|l|}{ Milk protein } \\
\hline $\mathrm{g} / \mathrm{d}$ & 562 & 537 & 532 & 435 & 47.7 & $* *$ & $\dagger$ & NS \\
\hline $\mathrm{g} / \mathrm{kg}$ & 28.1 & 28.2 & 28.8 & 28.4 & 0.55 & NS & NS & NS \\
\hline \multicolumn{9}{|l|}{ Casein } \\
\hline $\mathrm{g} / \mathrm{d}$ & 471 & 442 & 431 & 350 & 38.9 & $* *$ & $\dagger$ & NS \\
\hline $\mathrm{g} / \mathrm{kg}$ & 23.4 & 23.2 & 23.4 & 22.7 & 0.41 & $\dagger$ & NS & NS \\
\hline \multicolumn{9}{|l|}{ Whey protein } \\
\hline $\mathrm{g} / \mathrm{d}$ & 104 & 98 & 107 & 92 & 9.70 & NS & NS & NS \\
\hline $\mathrm{g} / \mathrm{kg}$ & 5.19 & 5.16 & 5.80 & 6.03 & 0.450 & $*$ & NS & NS \\
\hline Casein/whey protein & 4.53 & 4.56 & 4.08 & 3.84 & 0.274 & $* *$ & $\dagger$ & NS \\
\hline \multicolumn{9}{|l|}{ Milk fat } \\
\hline $\mathrm{g} / \mathrm{d}$ & 718 & 699 & 756 & 652 & 55.6 & NS & NS & $\dagger$ \\
\hline $\mathrm{g} / \mathrm{kg}$ & 36.2 & 36.9 & 40.9 & 43.0 & 2.70 & $* *$ & NS & NS \\
\hline $\mathrm{C}_{4}$ to $\mathrm{C}_{10}, \%$ & 13.4 & 13.3 & 12.6 & 12.8 & 0.407 & $*$ & NS & NS \\
\hline $\mathrm{C}_{11}$ to $\mathrm{C}_{14}, \%$ & 17.0 & 17.0 & 17.0 & 16.9 & 0.335 & NS & NS & NS \\
\hline $\mathrm{C}_{16}, \%$ & 36.5 & 38.2 & 37.2 & 38.5 & 0.760 & $* *$ & NS & * \\
\hline $\mathrm{C}_{18}, \%$ & 33.6 & 32.1 & 33.8 & 32.3 & 0.674 & $\dagger$ & NS & $* *$ \\
\hline \multicolumn{9}{|l|}{ Lactose } \\
\hline $\mathrm{g} / \mathrm{d}$ & 900 & 879 & 843 & 730 & 84.1 & $*$ & NS & NS \\
\hline $\mathrm{g} / \mathrm{kg}$ & 49.5 & 49.5 & 49.8 & 47.6 & 1.13 & $\dagger$ & $\dagger$ & NS \\
\hline
\end{tabular}

${ }^{1} \mathrm{RMSE}=$ Root mean square error.

${ }^{2}$ Linear $(\mathrm{L})$, quadratic $(\mathrm{Q})$, and cubic $(\mathrm{C})$ effects.

$\dagger P \leq 0.10$; $* P \leq 0.05 ; * * P \leq 0.01$. 
Table 3. Effect of milking frequency on milk metabolite levels and ratios after $7 \mathrm{~d}$ of treatments from the left half-udder in dairy cows

\begin{tabular}{|c|c|c|c|c|c|c|c|c|}
\hline & \multicolumn{4}{|c|}{ Milking interval (h) } & \multirow[b]{2}{*}{$\mathrm{RMSE}^{1}$} & \multicolumn{3}{|c|}{ Effects $^{2}$} \\
\hline & 8 & 12 & 16 & 24 & & $\mathrm{~L}$ & Q & $\mathrm{C}$ \\
\hline \multicolumn{9}{|l|}{ Metabolites, $\mu \mathrm{mol} / \mathrm{L}$} \\
\hline Glucose-6-phosphate & 100 & 103 & 104 & 88 & 13.1 & NS & NS & NS \\
\hline Glucose-1-phosphate & 68.7 & 54.3 & 40.6 & 21.6 & 12.8 & $* *$ & NS & NS \\
\hline \multicolumn{9}{|l|}{ Ratio, $\mu \mathrm{mol} / \mu \mathrm{mol}$} \\
\hline Glucose-6-phosphate/glucose & 0.139 & 0.135 & 0.164 & 0.149 & 0.0213 & NS & NS & NS \\
\hline
\end{tabular}

${ }^{1} \mathrm{RMSE}=$ Root mean square error.

${ }^{2}$ Linear (L), quadratic (Q), and cubic (C) effects.

$* P \leq 0.05 ; * * P \leq 0.01$.

16- and 24-h milking intervals. The AVD for glucose decreased linearly by $0.108 \mathrm{mmol} / \mathrm{L}$ between the 8 - and 24-h milking intervals. The glucose extraction rate decreased curvilinearly; it did not vary between the 8and 16-h milking intervals and decreased from 26.8 to $23.3 \%$ between the 16 - and 24 -h milking intervals.

Arterial concentrations of $\alpha$-amino nitrogen did not vary with treatments. The AVD and extraction rate decreased numerically but failed to be significant because of a high root mean square error (AVD: $P=0.105$ and extraction rate: $P=0.108$ for linear effect). The
AVD and extraction rate were reduced as from the 16$\mathrm{h}$ milking interval treatment.

The arterial concentration and AVD of acetate tended to vary quadratically, with minimum values being observed with an 8-h milking interval and maximum values with the 12 -h milking interval. The acetate extraction rate remained unchanged by treatments. Arterial concentrations of BHBA increased linearly but not significantly by $0.27 \mathrm{mmol} / \mathrm{L}$ between the 8 - and 24 -h milking intervals $(P=0.133)$; its AVD remained unchanged by treatments. The extraction rate of BHBA tended to

Table 4. Effect of milking frequency on arterial concentrations, arteriovenous difference of concentrations (AVD) and extraction rates of glucose, lactate, $\alpha$-amino nitrogen, acetate, BHBA, total glycerol, and NEFA after $7 \mathrm{~d}$ of different treatments from the left half udder in dairy cows

\begin{tabular}{|c|c|c|c|c|c|c|c|c|}
\hline & \multicolumn{4}{|c|}{ Milking interval (h) } & \multirow[b]{2}{*}{$\mathrm{RMSE}^{1}$} & \multicolumn{3}{|c|}{ Effect ${ }^{2}$} \\
\hline & 8 & 12 & 16 & 24 & & $\mathrm{~L}$ & $\mathrm{Q}$ & $\mathrm{C}$ \\
\hline \multicolumn{9}{|l|}{ Glucose } \\
\hline Arterial concentration, $\mathrm{mmol} / \mathrm{L}$ & 3.59 & 3.50 & 3.53 & 3.74 & 0.119 & NS & $*$ & NS \\
\hline $\mathrm{AVD}, \mathrm{mmol} / \mathrm{L}$ & 0.977 & 0.960 & 0.947 & 0.869 & 0.0531 & * & NS & NS \\
\hline Extraction rate, \% & 27.2 & 27.4 & 26.8 & 23.3 & 1.39 & $* *$ & * & NS \\
\hline \multicolumn{9}{|l|}{$\alpha$-Amino nitrogen } \\
\hline Arterial concentration, $\mathrm{mmol} / \mathrm{L}$ & 3.19 & 3.13 & 2.98 & 3.19 & 0.159 & NS & NS & NS \\
\hline $\mathrm{AVD}, \mathrm{mmol} / \mathrm{L}$ & 0.743 & 0.723 & 0.563 & 0.639 & 0.1231 & NS & NS & NS \\
\hline Extraction rate, $\%$ & 23.2 & 23.1 & 19.0 & 20.0 & 3.47 & NS & NS & NS \\
\hline \multicolumn{9}{|l|}{ Acetate } \\
\hline Arterial concentration, $\mathrm{mmol} / \mathrm{L}$ & 2.09 & 2.33 & 2.28 & 2.15 & 0.122 & NS & * & NS \\
\hline $\mathrm{AVD}, \mathrm{mmol} / \mathrm{L}$ & 1.49 & 1.69 & 1.54 & 1.52 & 0.115 & NS & $\dagger$ & NS \\
\hline Extraction rate, $\%$ & 71.4 & 72.7 & 68.3 & 70.7 & 4.10 & NS & NS & NS \\
\hline \multicolumn{9}{|l|}{ BHBA } \\
\hline Arterial concentration, $\mathrm{mmol} / \mathrm{L}$ & 1.05 & 1.23 & 1.22 & 1.32 & 0.240 & NS & NS & NS \\
\hline $\mathrm{AVD}, \mathrm{mmol} / \mathrm{L}$ & 0.434 & 0.466 & 0.440 & 0.431 & 0.0784 & NS & NS & NS \\
\hline Extraction rate, $\%$ & 42.3 & 40.0 & 38.0 & 34.4 & 5.28 & $\dagger$ & NS & NS \\
\hline \multicolumn{9}{|l|}{ Total glycerol } \\
\hline Arterial concentration, $\mu \mathrm{mol} / \mathrm{L}$ & 67.2 & 67.6 & 74.6 & 72.3 & 2.44 & $* *$ & NS & * \\
\hline $\mathrm{AVD}, \mu \mathrm{mol} / \mathrm{L}$ & 24.6 & 24.4 & 26.6 & 22.2 & 2.50 & NS & NS & NS \\
\hline Extraction rate, \% & 36.6 & 36.4 & 35.7 & 30.8 & 3.06 & * & $\dagger$ & NS \\
\hline \multicolumn{9}{|l|}{ NEFA } \\
\hline Arterial concentration, $\mu \mathrm{mol} / \mathrm{L}$ & 77.5 & 77.8 & 74.6 & 62.0 & 3.54 & $* * *$ & $* *$ & NS \\
\hline $\mathrm{AVD}, \mu \mathrm{mol} / \mathrm{L}$ & -7.7 & -9.2 & -7.3 & -21.7 & 11.0 & NS & NS & NS \\
\hline
\end{tabular}

${ }^{1} \mathrm{RMSE}=$ Root mean square error.

${ }^{2}$ Linear (L), quadratic (Q), and cubic (C) effects.

$\dagger P \leq 0.10 ; * P \leq 0.05 ; * * P \leq 0.01 ; * * * P \leq 0.001$. 
Table 5. Effect of milking frequency on mammary epithelial integrity after $7 \mathrm{~d}$ of treatments in dairy cows

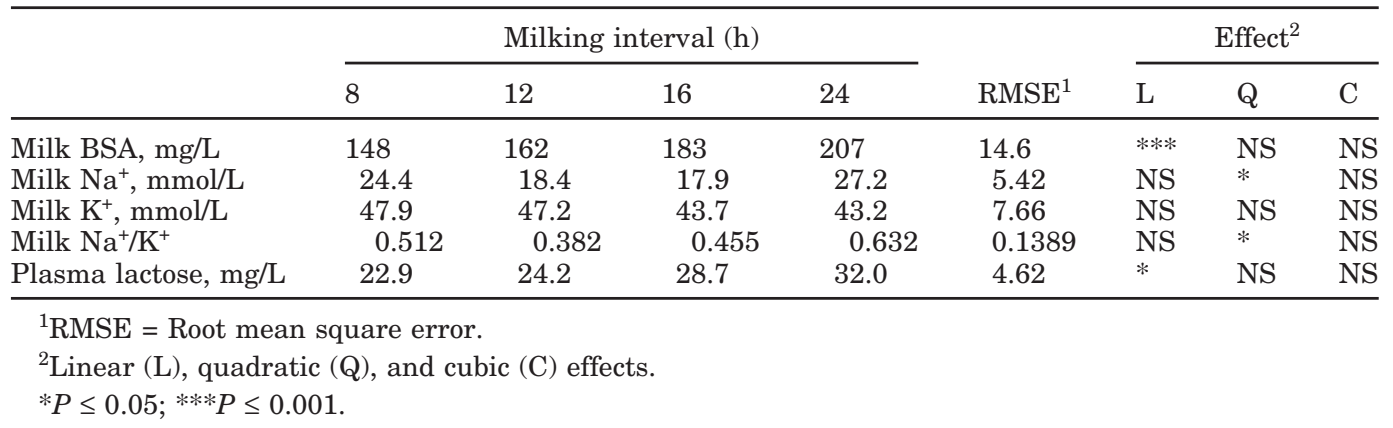

decrease linearly from 42.3 to $34.4 \%$ between the 8 and 24-h milking intervals. The arterial concentrations of total glycerol did not vary between the 8 - and $12-\mathrm{h}$ milking intervals, increased between the 12- and 16-h intervals and remained unchanged between the 16- and 24-h intervals. The AVD remained unchanged by treatments and the extraction rate tended to decrease curvilinearly. It did not vary between the 8- and 16 -h milking intervals and decreased from 35.7 to $30.8 \%$ between the 16- and 24-h milking intervals. Arterial concentrations of NEFA decreased curvilinearly as from the 16$\mathrm{h}$ milking interval and fell by $12.6 \mu \mathrm{mol} / \mathrm{L}$ between the 16- and 24-h milking intervals, whereas the AVD for NEFA remained unaffected by increasing milking intervals.

\section{Mammary Epithelial Permeability}

As the milking intervals became longer, milk BSA levels increased linearly by $59 \mathrm{mg} / \mathrm{L}$ between the 8 - and 24-h milking intervals (Table 5). The milk $\mathrm{Na}^{+}$content varied quadratically, reaching a minimum of 17.9 $\mathrm{mmol} / \mathrm{L}$ with the 16 -h milking interval treatment. The milk $\mathrm{K}^{+}$content was unaffected by treatments. Consequently, the $\mathrm{Na}^{+} / \mathrm{K}^{+}$milk ratio varied, reaching a minimum of 0.382 with the 16 -h milking interval treatment. Average plasma lactose concentrations increased linearly by $9.1 \mathrm{mg} / \mathrm{L}$ with increasing milking intervals.

\section{DISCUSSION}

\section{Milk Yield, Milk Protein Yield, and Milk Fat Yield}

Milk yield declined curvilinearly in response to a reduction in milking frequency. Unlike the data reported by Barnes et al. (1990), DePeters et al. (1985), Pearson et al. (1979), and Szûcs et al. (1988), milk yield was not affected by a change in the milking interval from 8 to $12 \mathrm{~h}$. This could be due to the too-short duration of the experiment, the advanced lactation stage of animals, and/or a nonexcess energy intake when an 8-h milking interval was allowed. When the milking interval was
$16 \mathrm{~h}$, milk yield started to decline $(3.3 \mathrm{~kg} / \mathrm{d}$ lower $)$, as had already been observed in cows milked 3 times every $2 \mathrm{~d}$ for 5 wk (Rémond and Boît, 1997) or throughout lactation (Eldridge and Clark, 1978). When the milking interval was $24 \mathrm{~h}$, the milk yield was reduced by 9.1 $\mathrm{kg} / \mathrm{d}$ between the $12-$ and $24-\mathrm{h}$ milking intervals, as had been observed previously during comparable experimental periods (Davis et al., 1999).

The reduction in protein yield was also curvilinear. Protein levels changed little under the different regimens, because of similar reductions in milk yield and protein yield. Similar observations had previously been made in cows milked 3 times in $2 \mathrm{~d}$ (Rémond and Boît, 1997) or once a day (Davis et al., 1999). Milk fat yield declined linearly and to a lesser extent than milk yield, causing an increase in the milk fat level. Thus, between intervals of 12- and 16 -h, the milk fat level rose by 1.2 $\mathrm{g} / \mathrm{kg}$. With a 24 -h milking interval, this phenomenon was amplified and the milk fat level rose by $6.2 \mathrm{~g} / \mathrm{kg}$, as had been reported in animals milked once a day (Davis et al., 1999; Rémond and Pomiès, 2004).

\section{Mammary Extraction of Nutrients}

During this study, the reduction in daily milk yield was associated with a reduction in the mammary extraction of nutrients. These reductions in the extraction rates of nutrients suggested that the mammary gland's ability to extract nutrients was impaired in response to increasing milking intervals. The extraction rates of glucose, $\alpha$-amino nitrogen, BHBA, and total glycerol decreased or tended to decrease significantly (declines of 3.2 to $7.9 \%$ ) between the 8- and 24-h milking intervals, except for acetate, for which the extraction rate did not differ as a function of interval.

In this study, the extraction rates appeared to be regulated differently depending on the metabolic fate of nutrients. This observation may explain, at least in part, why the production of protein and lactose (and hence, milk yield) were reduced more than the milk fat yield. The extraction of glucose and protein precursors 
appeared to be much more markedly regulated than that of milk fat precursors. Indeed, only the decrease in the extraction rate of glucose and $\alpha$-amino nitrogen could be partly explained by a drop in the AVD, the latter reaching more than $0.10 \mathrm{mmol} / \mathrm{L}$ regarding glucose and $\alpha$-amino nitrogen. In the goat, a drop in the AVD for glucose had also been observed but occurred later; that is, after the third day without milking (Fleet and Peaker, 1978). In addition, in female rats, a reduction in the AVD of amino acids was also observed after $5 \mathrm{~h}$ of milk accumulation (Vina et al., 1981). Regulation of the extraction of milk fat precursors (both short and long fatty acid precursors) appeared to be exerted less markedly: either the AVD was not modified by different treatments (BHBA, total glycerol) or a reduction in the AVD was correlated positively with a reduction in the arterial concentration (acetate). This depressed ability of the mammary gland to extract nutrients could result from different processes of intracellular regulation, which may be linked to the types of nutrient taken up.

\section{Intramammary Regulatory Mechanisms}

The first level of intramammary regulation could concern the transmembrane transport of glucose and protein precursors. Indeed, only nutrients whose transmembrane transport is ensured by transport proteins (Shennan and Peaker, 2000); that is, glucose and protein precursors, experience a decrease in their AVD. In contrast, the AVD of nutrients diffusing passively through the plasma membrane (Davis and Collier, 1985), such as milk fat precursors (acetate, BHBA, or glycerol), is either maintained or diminished because of a drop in their arterial concentration. The hypothesis that transport proteins are involved in regulating nutrient extraction is consistent with the decrease of 145 $\mu \mathrm{mol} / \mathrm{L}$ in the milk glucose concentration observed in this study. Indeed, according to Faulkner (1980), the glucose content in milk is proportional to its intracellular concentration. If this hypothesis is true, the glucose content in milk should have increased in response to the increased arterial concentration of glucose if the transporters of glucose had not been regulated. According to Shennan and McNeillie (1994), milk accumulation in the female rat may also negatively regulate the extraction of amino acids by the mammary gland via systems of amino acid transporters.

The second level of intramammary regulation could also be exerted on the metabolic use of nutrients. Farr et al. (1995) and Wilde and Knight (1990) observed a reduction in the activity of enzymes involved in lactose synthesis (galactosyltransferase) or triglyceride synthesis (acetyl-CoA carboxylase, fatty acid synthetase) in cows and goats milked once daily. In this study, the mammary metabolic activity, especially that of glucose, was reduced. The glucose conversion into lactose synthesis appeared altered. Our data provide some idea that the lactose synthesis could be limited at the first steps of the metabolic pathway of the lactose synthesis. The intracellular glucose concentration, which is known to be a limiting factor governing lactose synthesis (Kuhn et al., 1980), diminished during our study when estimated from its level in milk. The first reaction of the intracellular metabolism of glucose (the conversion of glucose into glucose-6-phosphate catalyzed by a glucokinase) appeared to be preserved, regardless of the milking interval. The glucose-6-phosphate concentration and glucose/glucose-6-phosphate ratio remained constant. But the phosphoglucomutase, which permitted the conversion of glucose-6-phosphate into glucose1-phosphate, also could be strongly downregulated. The glucose-1-phosphate/glucose-6-phosphate ratio was divided in half between 8- and 24-h milking intervals, causing a reduction of $47 \mu \mathrm{mol} / \mathrm{L}$ in the glucose-1-phosphate concentration.

\section{Mammary Epithelial Permeability}

In the literature, it is accepted that exchanges between alveolar and blood compartments reflect mammary epithelial permeability (Stelwagen, 2001). During our study, an increase in exchanges of lactose, BSA, and ions between the blood and alveolar compartments was observed indicating a change in the mammary epithelial permeability in response to an increase in the milking interval. Increases in BSA concentrations in milk and plasma lactose levels were correlated positively $\left(\mathrm{R}^{2}=0.99, \mathrm{n}=4\right)$, which is not the case with the $\mathrm{Na}^{+} / \mathrm{K}^{+}$ratio. This ratio increased quadratically in response to treatments perhaps in response to compensation phenomena, allowed by the existence of active $\mathrm{Na}^{+}$and $\mathrm{K}^{+}$ion transport in the membranes (Shennan and Peaker, 2000).

With regard to our milk BSA and plasma lactose results, the mammary epithelium could be sensitive to every change in milking frequency. Indeed, the increase in the exchanges between acini and blood was linear when the milking interval became longer. This result confirms what is indicated by data in the literature: an increase in mammary epithelial permeability occurs when milking interval increases. Indeed, in cows milked once daily, an increase in the mammary epithelial permeability has been observed in numerous studies (Davis et al., 1999). Rémond and Boît (1997) also reported this phenomenon in cows milked 3 times in 2 $\mathrm{d}$ during their first $3 \mathrm{wk}$ of lactation. In dairy cows, Sorensen et al. (2001) observed greater mammary epi- 
thelial impermeability in half udders milked twice daily when compared with quarters milked 3 times a day.

According to the reviews of Davis et al. (1999) and Stelwagen (2001), the tight junctions may be at the origin of the reduced milk yield observed when the milking interval increases. Thus, Stelwagen (2001) suggested that a reduction in prolactin secretion associated with conformational changes to cells, due to mechanotransduction mechanisms, might give rise to the opening of tight junctions. This could lead to modifications of the cell cytoskeleton causing a reduction in milk yield. In the current study, the opening of the tight junctions responded linearly to an increase in milking intervals; the reduction in milk yield was curvilinear. These observations tend to suggest that if the tight junctions are involved in regulating milk yield, they could only intervene as from a certain threshold of the degree of mammary epithelial permeability. The opening of the tight junctions would not affect milk yield in cows milked more than twice daily compared with those milked at 12 -h intervals. Our results showed that in cows milked thrice daily, although the mammary epithelium permeability was decreased, the milk yield did not increase. However, in cows milked less than twice daily, tight junctions could be involved in regulation of milk yield. The decrease in milk yield was associated with an increase in mammary epithelium permeability as shown in this study with milking frequencies having milking intervals of 16 or $24 \mathrm{~h}$. This hypothesis is consistent with other observations on milk composition because the increase in soluble protein levels is only affected by milking intervals of more than $12 \mathrm{~h}$.

Questions are raised concerning the existence of a link between the opening of the tight junctions and reduced nutrient extraction. Indeed, one of the roles of tight junctions is to separate the plasma membrane into basolateral and apical regions and thus participate in maintaining the asymmetrical distribution of ion channels, pumps, and transporters in the plasma membrane (Schneeberger and Lynch, 1992). Therefore, if tight junctions become very loose, cell polarity is disturbed, and the distribution of transporters no longer respected. This disturbance might explain why a reduction in AVD and the rate of extraction of nutrients whose transport to cells is ensured by a transport protein, is so pronounced when a 24 -h milking interval is allowed. This process could occur simultaneously with others described in the literature such as the downregulation of the transcription (Yang et al., 2005), the spoiling of some enzymatic activities (Wilde and Knight, 1990; Farr et al., 1995), or the altered migration of the secretory vesicles toward the apical membrane of cell (Stelwagen, 2001).

\section{CONCLUSIONS}

With longer milking intervals, reduction in milk yield is associated with loss of the mammary gland's ability to extract the principal nutrient precursors of milk components. However, it appears that the mechanisms regulating nutrient extraction by the mammary gland could be exerted differently. The extraction of glucose and protein precursors is more markedly regulated than that of milk fat precursors. This difference could explain, at least in part, why milk yield and protein yield diminish more than milk fat yield. Furthermore, the reduction in milk yield is curvilinear and associated with a linear increase in the mammary epithelial permeability, suggesting that if the tight junctions are involved in regulation of milk yield, their role in milk yield may only intervene as a threshold degree of mammary epithelial permeability.

\section{ACKNOWLEDGMENTS}

The authors would like to thank Y. Lebreton for assistance with surgical procedures, P. Lamberton and his team for their help with the care and feeding of cows, and M. Texier, I. Jicquel, A. Brasseur, S. Rigault, L. Finot, S. Letort-Wiart, N. Huchet, and M. Vérité for technical assistance. Our thanks also go to D. Levieux (SRV-Immunochimie, INRA, Theix, France) for help with BSA immunodiffusion assays. The authors would like to thank V. Hawken for the English translation.

\section{REFERENCES}

Barnes, M. A., R. E. Pearson, and A. J. Luke-Wilson. 1990. Effects of milking frequency and selection for milk yield on productive efficiency of Holstein cows. J. Dairy Sci. 73:1603-1611.

Bauchard, D., and F. Duboisset. 1983. Utilisation des colonnes capillaires de verre pour l'analyse des acides gras du lait. Cah. Tech. Inst. Natl. Rech. Agron., Bull. Liaison Int. 1:1-53.

Davis, S. R., and R. J. Collier. 1985. Mammary blood flow and regulation of substrate supply for milk synthesis. J. Dairy Sci. 68:1041-1058.

Davis, S. R., V. C. Farr, and K. Stelwagen. 1999. Regulation of yield loss and milk composition during once-daily milking: A review. Livest. Prod. Sci. 59:77-94.

DePeters, E. J., N. E. Smith, and J. Acedo-Rico. 1985. Three or two times daily milking of older cows and first lactation cows for entire lactations. J. Dairy Sci. 68:123-132.

Eldridge, G. A., and J. Clark. 1978. Production of cows milked 3 times each 2 days. J. Dairy Res. 45:509-513.

Farr, V. C., K. Stelwagen, M. A. Kerr, S. R. Davis, and S. J. Eichler. 1995. Effect of once daily milking (ODM) on enzyme activities in the bovine mammary gland. Proc. N. Z. Soc. Anim. Prod. 55:12-13.

Faulkner, A. 1980. The presence of cellular metabolites in milk. Biochim. Biophys. Acta 630:141-145.

Fleet, I. R., and M. Peaker. 1978. Mammary function and its control at the cessation of lactation in the goat. J. Physiol. 279:491-507.

Guinard, J., H. Rulquin, and R. Vérité. 1994. Effect of graded levels of duodenal infusions of casein on mammary uptake in lactating cows. 1. Major nutrients. J. Dairy Sci. 77:2221-2231.

Hurtaud, C., H. Rulquin, and R. Vérité. 1993. Effect of infused volatile fatty acids and caseinate on milk composition and coagulation in dairy cows. J. Dairy Sci. 76:3011-3020. 
Institut National de la Recherche Agronomique (INRA). 1989. Introduction. Feeding standards for ruminants. Pages 15-22 in Ruminant Nutrition. Recommended Allowances and Feed Table. R. Jarrige, ed. John Libbey, Eurotext, London, UK.

Klei, L. R., J. M. Lynch, D. M. Barbano, P. A. Oltenacu, A. J. Lednor, and D. K. Bandler. 1997. Influence of milking three times a day on milk quality. J. Dairy Sci. 80:427-436.

Kuhn, N. J., D. T. Carrick, and C. J. Wilde. 1980. Lactose synthesis: The possibilities of regulation. J. Dairy Sci. 63:328-336.

Levieux, D. 1991. Dosage des IgG du lait de vache par immunodiffusion radiale semi-automatisée, pour la détection du colostrum, des laits de mammites ou de fin de gestation. I. Mise au point de dosage. Lait 71:327-338.

Linzell, J. L. 1974. Mammary blood flow and methods of identify and measuring precursors of milk. Pages 143-225 in Lactation. Vol. I. B. L. Larson and V. R. Smith, ed. Academic Press, New York, NY.

Pearson, R. E., L. A. Fulton, P. D. Thompson, and J. W. Smith. 1979. Three times a day milking during the first half of lactation. J. Dairy Sci. 62:1941-1950.

Rémond, B., and M. P. Boît. 1997. Effects of milking three times in 2 days for 3 weeks in early lactation or in the declining phase on milk production in primiparous and multiparous dairy cows. Ann. Zootech. 46:339-348.

Rémond, B., and D. Pomiès. 2004. Effect of once daily milking in dairy cows: A review of recent French experiments. 55th EAAP Annual Meeting, Bled, Slovenia. Wageningen Academic Press, Wageningen, The Netherlands.

SAS Institute. 1990. SAS User's Guide: Statistics. Version 6, ed 4. SAS Institute, Inc., Cary, NC.

Schneeberger, E. E., and R. D. Lynch. 1992. Structure, function, and regulation of cellular tight junctions. Am. J. Physiol. 262:L647-L661.
Shennan, D. B., and S. A. McNeillie. 1994. Milk accumulation downregulates amino acid uptake via systems $\mathrm{A}$ and $\mathrm{L}$ by lactating mammary tissue. Horm. Metab. Res. 26:611.

Shennan, D. B., and M. Peaker. 2000. Transport of milk constituents by the mammary gland. Physiol. Rev. 80:925-951.

Sorensen, B. A., D. D. Muir, and C. H. Knight. 2001. Thrice-daily milking throughout lactation maintains epithelial integrity and thereby improves milk protein quality. J. Dairy Res. 68:15-25.

Stelwagen, K. 2001. Effect of milking frequency on mammary functioning and shape of the lactation curve. J. Dairy Sci. 84(E. Suppl.):E204-E211.

Stelwagen, K., S. R. Davis, V. C. Farr, C. G. Prosser, and R. A Sherlock. 1994. Mammary epithelial cell tight junction integrity and mammary blood flow during an extended milking interval in goats. J. Dairy Sci. 77:426-432.

Stelwagen, K., V. C. Farr, S. R. Davis, and C. G. Prosser. 1995. EGTAinduced disruption of epithelial cell tight junctions in the lactating caprine mammary gland. Am. J. Physiol. 269:R848-R855.

Szûcs, E., I. Acs, K. Ugry, M. Sas, I. Tôrôk, and E. Fodor. 1988. Three times a day milking in high productivity cow stock. Acta Agron. Hung. 37:123-133.

Thivierge, M. C., D. Petitclerc, J. F. Bernier, Y. Couture, and H. Lapierre. 2002. Variations in mammary metabolism during the natural filling of the udder with milk over a 12 -h period between two milkings. J. Dairy Sci. 85:1839-1854.

Vina, J. R., I. R. Puertes, and J. Vina. 1981. Effect of premature weaning on amino acid uptake by the mammary gland of lactating rats. Biochem. J. 200:705-708.

Wilde, C. J., and C. H. Knight. 1990. Milk yield and mammary function in goats during and after once-daily milking. J. Dairy Res. $57: 441-447$.

Yang, J., B. Zhao, V. E. Baracos, and J. J. Kennelly. 2005. Effects of bovine somatotropin on beta-casein mRNA levels in mammary tissue of lactating cows. J. Dairy Sci. 88:2806-2812. 